\title{
Asymmetries in the phonological behaviour of Dagbani place features: Implications for markedness ${ }^{1}$
}

\author{
Fusheini Hudu \\ Senior Lecturer \\ Department of Linguistics \\ University of Ghana, Legon, Ghana \\ E-mail: fahudu@ug.edu.gh; hudu28@gmail.com
}

Submitted: March 11, 2018 / Accepted: October 18, 2018 / Published: December 3, 2018

\begin{abstract}
It has been observed in phonological studies that phonological processes often apply to place features in asymmetrical ways. Certain processes may affect only one of the place features, others may affect all but one place feature. This paper analyses various asymmetrical phonological patterns in Dagbani, a Gur language of Ghana. It shows that while the dorsal place is the target of most processes that lead to the loss of underlying place features, the labial and coronal places are targets of processes that enhance underlying place specifications. Labial-dorsals $[\mathrm{kp}, \mathrm{gb}, \mathrm{ym}]$ also surface in patterns of neutralisation with dorsals. Evidence from both diachronic and synchronic sound patterns suggest active sound changes in progress with the labial-dorsals being preferred to plain dorsals. The paper discusses the implication of these findings for the understanding of the theory of markedness and questions the widely held view of segmental complexity as a markedness diagnostic.
\end{abstract}

Keywords: markedness, complex segments, place features, Dagbani, Gur language

\section{Introduction}

This paper studies the nature of place feature specifications in the phonology of Dagbani, a Gur language spoken natively by the Dagomba and Nanumba ethnic groups of Northern Ghana, and the markedness conclusions that can be drawn from various phonological processes that affect these place specifications. Dagbani consonants are categorised under four distinctive major

1 Many thanks to the three anonymous reviewers for their useful comments. The preparation of the manuscript for publication benefited from a writing workshop for faculty members of the University of Ghana that I attended in February 2018. It was funded by Carnegie Corporation of New York. 
places of articulation: labial, coronal, dorsal and labial-dorsal. As in every natural language, a full understanding of the nature of these place specifications cannot be attained without examining their behaviour in various morpho-phonological contexts. When phonological processes occur, the place, manner, laryngeal or prosodic features of segments may be targeted. There are three ways in which underlying feature specifications of sounds may behave under phonological processes. First, certain processes serve the purpose of enhancing the presence of these specifications. This may take the form of introducing a place feature that does not exist underlyingly or enhancing the underlying presence of a feature that would otherwise exist in a weak form. Second, the phonological process may eliminate the presence or reduce the strength of an underlying feature specification. Finally, the underlying feature specification may be impervious to the effects of the phonological process. A phonological process applies asymmetrically when it affects certain feature specifications (especially leading to a loss or reduction) and enhances the presence of others or leaves them impervious to its effects.

The focus of this paper is on the effects of phonological processes on the place feature specifications of consonants in Dagbani and what these effects reveal about the relative markedness of these place specifications. The observed patterns show that of the four major place specifications, dorsals are the most often targeted by processes that lead to the loss of distinctive place specifications. In other words, forms with underlying dorsals surface without the dorsal place feature in many contexts. Dorsals are subject to some patterns of neutralisation that other place specifications are not subject to, some of which produce surface labial-dorsals. By contrast, coronals and labials are targets of processes that enhance their presence.

In presenting the various analyses, the paper discusses possible diachronic changes Dagbani may have undergone by comparing surface forms of words in Dagbani to same words in close Gur relatives such as Mampruli and Gurene. Even within native Dagbani vocabulary, certain processes apply optionally and 
with clear biases among speakers of different generations, such that younger speakers are more likely to apply the processes than older ones. This suggests a language change still in progress. Some efforts are also made to draw on crosslinguistic observations to put these observations in a typological context.

In this respect, the paper discusses what these observations imply as far as the theory of phonological segmental markedness is concerned. The concept of markedness is based on the observation that there is some disparity in the overall prevalence of various linguistic units or structures due to varying levels of preference languages show for these units and structures. Certain units are preferred, and are, for that matter, common within and across languages. Such units or structures are referred to as unmarked or less marked units. Other units, on the other hand, are dispreferred, resulting in their relative rarity. Such units are marked. Linguists from all sub-fields and theoretical persuasions have used several criteria to determine markedness, including the ease of articulation, the relative ease and order of acquisition by children, their participation in patterns of neutralisation and their relative complexity among others ${ }^{2}$. Of these diagnostics, the notion of complexity as a markedness diagnostic is of special interest to analysis in this paper. This is discussed further below. Of equal importance to the analysis is the issue of place feature markedness, discussed briefly in the next sub-section. This introductory section also presents the segment inventory and the basic word structure of Dagbani.

Most of the primary data used for the analyses are sourced from speakers of the Western/ Tomosili and the Eastern /Nayahili dialects, two of the three major dialects of the language, spoken by the Dagomba ethnic group. The third major dialect is Nanuni, spoken by the Nanumba ethnic group. Thus, unless otherwise noted, the data are representative of the Eastern and Western dialects. There are certain processes unique to only one of the three dialects. The data and discussion of such processes are noted as such. As a native speaker, I generated some of the data myself and sought the 2 See Haspelmath (2006), however, for arguments that the concept of markedness is dispensable. 
intuitions of other native speakers regarding them. Tone marking reflects the Eastern Dialect, which I speak natively. All data were collected from or confirmed by native speakers whose ages ranged between 28 and 70 years. A Dagbani dictionary (Naden, 2014) and a Gurene dictionary (Dakubu et. al., 2007) were also consulted for lexical items, dialectal variants of words as well as for English translations of some words.

\section{Place feature markedness}

The question of which place feature is universally (un) marked is as controversial as that of what the most reliable diagnostic of markedness is. In many studies (e.g. Kean, 1976; Mohanan, 1993; Paradis \& Prunet, 1991; Prince \& Smolensky, 1993), the coronal is deemed the unmarked place. However, other studies view the dorsal as less marked than other places features (e.g. Williamson, 1977; Harris 1990). Trigo (1988) argues for the dorsal as the unmarked place in codas while Rice (1996) argues that both coronal and dorsal are unmarked places. Lombardi $(2001,2002)$, on the other hand, views the glottal as the unmarked place with the dorsal more marked than the labial and coronal places. Hume and Tserdanelis (2002) also argue for the labial as the unmarked segment in Sri Lankan Portuguese Creole. Hume and Tserdanelis (2002) and Hume (2003) argue against a single universally unmarked place feature. To them, markedness can only be determined on a language-specific basis.

This paper aims at providing a closer look at the dorsal place relative to the labial, coronal and labial-dorsal places from a markedness perspective and to contribute to the debate on the strength of structural complexity as a universal markedness diagnostic. The notion that complex structures are marked is discussed further below.

\section{Complexity as a markedness diagnostic}

A complex segment, according to Sagey (1986), has multiple unordered articulations. In this sense, a "labiovelar [kp] will behave phonologically as both a labial and velar with respect to processes both on the left and on the right" (Sagey, 1986, p. 
99). Among the many references to complexity as a markedness diagnostic are Chomsky and Halle (1968), Greenberg (1969), Kaye et. al. (1985), Rice (1992), Dresher \& van der Hulst (1993) and Givón (1995). Greenberg argues for complex sounds to be more marked because "the more complex sound involves an additional articulatory feature and, correspondingly, an additional acoustic feature which is not present in the less complex sound. This additional feature is often called a "mark" and hence the more complex, less favored alternative is called marked and the less complex, more favored alternative the unmarked" (Greenberg, 1969, p. 476). Other studies that view markedness along the lines of articulatory effort are Calabrese (1995) and Hamilton (1996). Givón (1995) includes complexity among three broad markedness diagnostics viz. structural complexity, frequency of distribution and cognitive complexity. On structural complexity, Givón argues that "the marked structure tends to be more complex (or larger) than the corresponding unmarked one". Newmeyer (1992) also attributes relative complexity, including structural and semantic, to marked forms. Rice (1992) also claims that structure is tied to markedness when combined with absence of universally unmarked features at a node, "with more structure indicating a more marked segment and less structure a less marked segment" (Rice, 1992, p. 64). Assuming that neither labial nor dorsal is universally unmarked, a labial-dorsal consonant (e.g. kp, gb, $\mathrm{jm}$ ), must be more marked than a plain labial consonant ( $p, b, m)$. Similarly, the labial-dorsal must be more marked than a plain dorsal consonant $(\mathrm{k}, \mathrm{g}, \mathrm{\eta})$. Dresher and van der Hulst (1993) also define phonological complexity using branching nodes. A labial-dorsal is more complex, and for that matter more marked, than a plain dorsal or plain labial because it has two nodes: labial and dorsal. In other words, a labial-dorsal, may be the most marked place feature in a language that has it, if complexity is a dominant markedness diagnostic.

The notion that relative markedness implies relative complexity is also central to a number of phonological theories. In Chomsky and Halle (1968), relative markedness among elements 
is determined in part using quantity, with complexity of a system being the aggregate of the marked features of its members. The theory of charm and government posits that "the greater the number of elements in a compound segment, the greater its degree of markedness" (Kaye et. al., 1985, p. 313). Within Optimality Theory, the relative markedness of complex segments is generally assumed, as complex segments more often violate markedness constraints than simpler ones. In some studies (e.g. Padgett, 1995), markedness constraints such as *COMPSEG, specifically banning the surfacing of complex segments, have been proposed. As Hume (2011) observes, the understanding that markedness correlates with quantity is at the centre of some theories of underspecification (e.g. Kiparsky, 1982; Archangeli, 1984; Pulleyblank, 1988; Archangeli \& Pulleyblank, 1989) and most models of feature geometry (e.g. Clements, 1985; Avery \& Rice, 1989; Clements \& Hume, 1995). Within these theories of underspecification, the least marked element is understood to have the least amount of theoretical machinery. The equation of markedness with complexity is also central to the theory of charm and government which posits that "the greater the number of elements in a compound segment, the greater its degree of markedness" (Kaye et. al., 1985, p. 313).

Regardless of which of these place features (labial, coronal and dorsal) is assumed to be the most marked, all conceptualisations of the complexity diagnostic would predict that the most marked segment is one with more than one place specification when compared with segments with only one of the place features specified in the complex segments. In languages which have only labialdorsals as contrastive complex segments, this class of segments is predicted to be more marked than simplex labials and simplex dorsals. Alternatively, under a conception of markedness within which complexity does not play a (major) role, labial-dorsals could potentially be less marked than labials, coronals or dorsals. Under such a conception of markedness, any of the hierarchies in $/(1) b-e$ could hold for a language with labial-dorsals, given the hierarchy in (1)a (de Lacy 2002, 2006) for a language without labial-dorsals. 
(1) Place markedness hierarchy (' $\prec$ ' means less marked):

a. Coronal $\prec$ Labial $\prec$ Dorsal.

b. Coronal $\prec$ Labial $\prec$ Dorsal $\prec$ Labial-dorsal

c. Coronal $\prec$ Labial $\prec$ Labial-dorsal $\prec$ Dorsal

d. Coronal $\prec$ Labial-dorsal $\prec$ Labial $\prec$ Dorsal

e. Labial-dorsal $\prec$ Coronal $\prec$ Labial $\prec$ Dorsal

While any of the hierarchies could hold, the hierarchy in (1)c would be the most likely for a language with labial-dorsals if structure is not a major markedness diagnostic. Given that a labial-dorsal has both labial and dorsal features, the labial node of a labial-dorsal would mitigate the markedness of the complex node, rendering the labial-dorsal less marked than the plain dorsal. On the other hand, the dorsal node in the labial-dorsal would aggravate its markedness and render it more marked than the plain labial. The evidence from Dagbani segmental asymmetric patterns and patterns of neutralisation lends more support to the hierarchy Labial $\prec$ Labial-dorsal $\prec$ Dorsal, than the hierarchy Labial $\prec$ Dorsal $\prec$ Labial-dorsal, suggesting that the complexity of the labial-dorsal does not affect its relative markedness. Such an enquiry is of interest to the general analysis of the phonology of the dorsal place feature in Dagbani.

\section{Dagbani sound inventory}

Dagbani has 22 phonemic consonants and 10 vowel phonemes. The language has phonemic vowel length as well as many surface forms of vowels and consonants. These are shown in (2) and (3) along with surface variants, shown in brackets. 
(2) Consonant inventory

\begin{tabular}{|c|c|c|c|c|c|c|c|}
\hline Labial & \multirow{2}{*}{$\begin{array}{c}\text { Labial- } \\
\text { Cor. }\end{array}$} & \multicolumn{3}{|c|}{ Coronal } & $\begin{array}{l}\text { Labial- } \\
\text { Dorsal }\end{array}$ & Dorsal & \multirow{2}{*}{$\begin{array}{c}\text { Glottal } \\
{[?]} \\
\end{array}$} \\
\hline $\mathrm{p}$ & & $\mathrm{d}$ & & & $\mathrm{kp} \quad \mathrm{gb}$ & $\mathrm{k}$ & \\
\hline $\mathrm{m}$ & {$[\mathrm{nm}]$} & $\mathrm{n}$ & & $\mathrm{n}$ & $\mathrm{ym}$ & $\eta$ & \\
\hline & & & t $\quad d s$ & & & & \\
\hline $\mathrm{f}$ & & $\mathrm{s}$ & \begin{tabular}{|ll}
{$\left[\int\right]$} & {$[3]$} \\
\end{tabular} & & & {$[\mathrm{x}]$} & {$[\mathrm{h}]$} \\
\hline & & $1[\mathrm{r}]$ & & $\mathrm{j}$ & $\mathrm{W}$ & & \\
\hline
\end{tabular}

(3) Vowel inventory

Short vowels

i

i i

i

[u]

U

$[\mathrm{e}]$

$\varepsilon$

e:

o:

Long vowels

i:

$\mathrm{u}:$

a:

The velar fricative $[\mathrm{x}]$ is unique to a rural subdialect of the Western Dialect. As already noted, only segments under the labial, coronal, labial-dorsal and dorsal place features are distinctive. The labialcoronals $[\mathrm{tp}, \mathrm{db}, \mathrm{nm}]$ are respective variants of the labial-dorsals / $\mathrm{kp}, \mathrm{gb}, \mathrm{gm} /$ in the Eastern and Western Dialects, surfacing before front vowels (Ladefoged, 1968; Wilson \& Bendor-Samuel, 1969; Hudu et al., 2009). The glottal stop is a variant of $/ \mathrm{k}, \mathrm{g} /$ after vowels, while [h] is a variant of $/ \mathrm{s} /$ between two vowels in the Western Dialect. For typical speakers of the Eastern Dialect, postvocalic $/ \mathrm{k}, \mathrm{g} /$ and intervocalic $/ \mathrm{s} /$ are all realised as a glottal stop. The coronals /s, z/ also surface as [ $[, 3]$ before front vowels. Similarly, $/ \mathrm{d} /$ surfaces as a tap $[\mathrm{c}]$ in intervocalic position. Vowel distribution is governed mainly by the rules of various patterns of harmony, 
especially [ATR], backness and rounding, as discussed in extensive detail by previous researchers (Olawsky, 1999; Hudu, 2010, 2013, 2014a, 2014b).

The analysis presented here assumes a theory of features that sees a uniform application of place features to vowel and consonants (Clements \& Hume, 1995). Thus, in addition to the traditional vowel features [high], [low] and [ATR] (e.g. Sagey, 1986; Odden, 1991 , etc.), some of the vowels are also labial, coronal, dorsal or labial-dorsal, as consonants are. This is indicated in (4).

(4) Vowel features

\begin{tabular}{|c|c|c|c|c|c|c|c|c|c|c|}
\hline & $\mathrm{i}$ & $\mathrm{e}$ & $\varepsilon$ & $\mathrm{a}$ & $\partial$ & $\mathrm{i}$ & $\jmath$ & $\mathrm{o}$ & $\mathrm{u}$ & $\mathrm{u}$ \\
\hline$[$ high $]$ & + & - & - & - & - & + & - & - & + & + \\
\hline$[$ low $]$ & - & - & - & + & + & - & - & - & - & - \\
\hline$[$ ATR $]$ & + & + & - & - & + & - & - & + & - & + \\
\hline$[\mathrm{LAB}]$ & & & & & & & $\sqrt{ }$ & $\sqrt{ }$ & $\sqrt{ }$ & $\sqrt{ }$ \\
\hline$[$ COR $]$ & $\sqrt{ }$ & $\sqrt{ }$ & $\sqrt{ }$ & & & & & & & \\
\hline$[$ DOR $]$ & & & & & & & $\sqrt{ }$ & $\sqrt{ }$ & $\sqrt{ }$ & $\sqrt{ }$ \\
\hline
\end{tabular}

\section{Dagbani word structure}

As in other Gur languages, the structure of the Dagbani word is determined partly by its grammatical class (Olawsky, 1999; Miehe, 2012; Miehe et al., 2012; Hudu, 2005, 2010, 2014b). The typical simplex noun/adjective consists of a root bound to a nominal suffix. The suffix encodes number along with other semantic properties. Verbs, on the other hand, are largely free forms that may be inflected for aspectual or other markers. Given that the morphemes in nominal and adjectival forms are mutually bound to each other, segments in nominal roots often trigger phonological processes (e.g. assimilation, harmony, lenition) affecting segments in the suffix, and vice-versa. For this reason, determining the underlying feature specifications of segments in a nominal root or affix is often not straightforward. As discussed extensively in Hudu (2005, 2010, 2014b), a more reliable morphological context 
for determining the underlying forms of segments in nominal and adjectival roots is compound forms that consist of two or more nominal roots and one suffix. In such forms, the nominal roots that are non-adjacent to the nominal suffix typically surface in the underlying forms given that assimilatory processes are blocked when the trigger and target belong to different lexical roots. These details are illustrated with data in the sections that follow.

The rest of the paper is organised as follows. The next two sections look at various phonological processes that reveal the differing behaviour of place feature specifications. The first part discusses two phonological processes, lenition and fortition, that relate to the overall strength of segmental stricture but also affect the place specifications of sounds. The next part examines patterns of neutralisation resulting from assimilatory processes and coalescence. In both sections, the implication of these asymmetric observations for the theory of markedness is discussed. The discussion on patterns of neutralisation addresses the question of segmental complexity, demonstrating that in Dagbani, labial-dorsal are favoured in an active sound change that results in the loss of underlying plain dorsal sounds. The final section has the summary and conclusions.

\section{Segmental strength asymmetries in Dagbani}

Lenition and fortition are two broad categories of phonological processes that relate to the strength of segmental stricture and the place specifications of segments associated with these strictures. These are of relevance to the analyses in this paper because some patterns of lenition and fortition have the potential to trigger the loss of underlying place feature specifications. In this paper, only such patterns of lenition and fortition are discussed. A close study of lenition and fortition in Dagbani shows that while the dorsal place is targeted for loss in patterns of lenition, the labial and coronal places are the targets of enhancement in patterns of fortition. This accords with the widely held position of the dorsal as a more marked place than the labial and the coronal. These are discussed below. 


\section{Lenition}

Lenition typically carries the notion of some reduction in the degree of constriction of a sound (Bauer 1988; Kirchner 1998 etc.). These include degemination, debuccalisation, spirantisation, flapping and deletion. Of these processes, only deletion, degemination, debuccalisation, and spirantisation result in the loss of underlying place specifications in Dagbani. I present each process and its asymmetrical application to the various place features.

In order to fully appreciate the patterns of alternation discussed here and the conclusions drawn from them, the loss of oral constriction for the dorsals $/ \mathrm{g}, \mathrm{k} /$ and the coronal $/ \mathrm{s} /$ needs further highlighting. In Dagbani phonology, [?, h] are not phonemes. The glottal stop always surfaces as an allophone of $/ \mathrm{g} /$ or $/ \mathrm{k} /$ in all dialects (and /s/ in the Eastern Dialect); [h] surfaces as a variant of /s/ in the Western Dialect. There are no minimal pairs or cases of contrastive distribution between [?] and a velar stop nor between $/ \mathrm{s} /$ and [h] in the language. In the Western Dialect, [?] exists as an optional variant of $[\mathrm{k}, \mathrm{g}]$ in weak positions (affixes, particles, bound roots) among other environments, as shown later in this paper. In homophonous free-standing lexical forms, the velar stops maintain their dorsal place feature, as shown in (5). This is part of a general pattern of positional asymmetry observed in several phonological processes in Dagbani, as discussed extensively by Hudu (2014b).

(5) Positional effects in optional velar debuccalisation (Western Dialect) ${ }^{3}$

i focus marker (ka)

/jà ká ó bé/

[jà Pó: bé]

where foc. 3sg.anim. be "Where is s/he?"

ii. verb (ka)

Àbú ká ó jíná *[Abu Pá o jíná]

Abu absent 3sg.poss home "Abu is not at his home"

3 Abbreviations in this paper are: Foc. $=$ focus marker, imperf. $=$ imperfective, $\mathrm{N} .=$ noun, Nom. = nominal affix, perf. $=$ perfective marker, pl. = plural, sg. $=$ singular, V. $=$ verb 
The same positional effects are observed in the realisation of underlying /s/ as $[\mathrm{h}]$ in the Eastern Dialect, notwithstanding the general pattern of intervocalic realisation of $/ \mathrm{s} /$ as $[\mathrm{h}]$ shown in the next section. This is shown in (6).

(6) Positional effects in /s/ debuccalisation (Western Dialect)

i. Affix -si (pl. suffix)

/pí-sí-tá/ [pí-hí-tá]

ten-pl.-three

"thirty"

ii. Verb: sa (to plant)

/bì sà-já/ *[bì hà já]

3sg. plant-perf.

"They planted"

Another synchronic evidence supporting the velar-glottal alternation comes from Dagbani place names which contain the glottal stop. Because there is no letter in the Roman alphabet to faithfully represent the glottal stop, a different consonant is used in the official spelling and pronunciation of names of towns and villages in Dagbon which feature surface glottal stops. In such names, [g] is always used, as shown in (7). Even educated native speakers of Dagbani typically pronounce these names with [g], especially in the course of speaking English.

(7) [g] in place of [?] in official representation of Dagbon place name.

Official representation Actual Dagbani pronunciation
a $<$ Zabzugu $>$
[zábzứ̛̃] "name of a town",
b $<$ Gundogu $>$
[gưndó?ú] "name of a village close to
Yendi"
c $<$ Gushegu $>$
[gujøèró] "name of a town"
d $<$ Lamashegu $>$
[làmà हैं̛́] "name of a suburb of Tamale"
e $<$ Bagabaga $>$
[báPábá?á] "name of a suburb of Tamale". 


\section{Deletion}

Deletion is not a widespread phonological process in Dagbani. The only consonants discussed in the literature to show systematic deletion in Dagbani are $/ \mathrm{g} /$ and $/ 1 /$. For this reason, these are the only two consonants which can provide insight into the effects of deletion on the overall distribution of segments of different places of articulation. Hudu (2014b) has discussed lateral deletion in Dagbani, noting that it takes place both in suffix onset and root coda positions as a means of blocking the realisation of two adjacent coronals of different manner of articulation $[1, j]$. What is of interest to the discussion in this paper is the mere observation that the lateral, a coronal consonant does get deleted. In (8), the deletion of [1] in a nominal root is illustrated. Unlike the singular and compound forms of the words, the plural forms lack the coronal [1] ostensibly due to the presence of [j] as suffix onset.

(8) Nominal root [1] deletion before coronal [j] (Hudu, 2014b, p.

24)

UR singular plural compound

\begin{tabular}{|c|c|c|c|}
\hline a jíl- & jí-jâ & jíl pél-lí & "white house" \\
\hline b gál- & gá-já & gàl pèl-lí & "white thread" \\
\hline gól- $\hat{\mathbf{t}}$ & gó-jâa & gól pál-lí & "new moon (month)" \\
\hline gbál- & gbá-jâ & gbál búl-a & "small leg" \\
\hline jèvíl-í & nغ̀ví-jâ & jèvíl láná & "owner of a soul" \\
\hline
\end{tabular}

However, the lateral and other coronals get preserved in other hetero-morphemic contexts, including sequences of coronals and non-coronals and geminate laterals, as shown in (9).

(9) Preservation of nominal coronals in other contexts

$\mathrm{Sg}$. form
a. kj̀-gú
b. tờ-gâ
c. kưl-gá
d. kpál-gû́
e. kpàr-gû́

pl. form

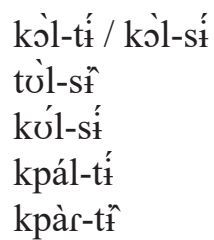

"a leather bag"

"pestle"

"river/dam"

"dawadawa spice"

"gawn" 
Hudu, F./ Asymmetries in the phonological behaviour of Dagbani place features
f. gbál-lí
gbál-á
"grave"
g. pál-lí
pál-á
"road"
h. kpàr-lí
kpàr-á
"baboon"
i. kpár-â
kpár-bá
"farmer"

The deletion of the plain dorsal is illustrated in (10) and (11). In (10), a [g] in an underlying CV:gi verb is deleted optionally in citation form and obligatorily in suffixed forms. It also deletes when followed by a CV clitic. In other words, in the citation form of these words, both the CV:gi and CV:i forms are used.

(10) Plain dorsal deletion
a. /dá:gî/ [dá:gî/dá:î] "push” dá:g á "push you”, dá: lí "push it"

b. /jò:gì/ [jò:gì/ jò:ì] "open" jò:g ó "open for him" jò: tí "open for

c. /tù:gì/ [tù:gì /tù:ì] "stumble" tù:-rá "stumbling" tú:bû "the act of ..."

d. /ló:gîl/ [ló:gî / ló:î] “infect” lò:-rá “infecting” ló:bû "the process of infecting"

e. /mò:gì/[ mò:gì /mò:ì] "ripen" mò:-rá "getting ripe" mò:sîm "state of being ripe"

In (11), underlying /g/, which generally surfaces as a glottal stop, as discussed further below, gets deleted entirely, especially in the Eastern Dialect. The forms with surface glottal stop and those with deleted dorsals are considered variants of the same words in all dialects. 
(11) Dorsal deletion (especially in the Eastern Dialect) UR /g/ Surface [?] UR /g/ deleted.
a. /zưg kóg-líz/
[zứ? kó?-lí]
[zư kó?-líi ] "a knock on
the head with the knuckles"
b. /zưg píl-gứl [zứr píl-gú] [zí púl-gứ] "head cover (hat)"
c. Inág tyím-bá/ [ná? tyím-bá] [ná ttím-bá] "young men"
d. /jígsì̀/
[jí?sìt]
[jísî̀]
"stand up"

The difference between lateral deletion and dorsal deletion is that, the former does not define the overall distributional pattern of the lateral or coronals in general. The lateral and other coronals surface in root-final and suffix-initial positions when the trigger of lateral deletion is lacking, as already illustrated in (9). The plain dorsal, on the other hand, is lost in intervocalic position (albeit optionally, when the first $\mathrm{V}$ is long) through various processes, one of which is deletion.

\section{Degemination}

Degemination, a process by which a geminate is reduced to a singleton, is illustrated in (12). Dorsal geminates are reduced to singletons, which further debuccalise and surface as glottal stops.

(12) Degemination (along with debuccalisation) ${ }^{4}$ :

a. /bók-kú/ [bó?-ú] "arm-sg." cf. [bó?-rí] "arm-pl.”, $\quad \begin{aligned} & \text { [bò? búl-á] } \\ & \text { small arm-sg." }\end{aligned}$

b. /zứg-gô/ [zứ-ô]] "head-sg.” cf. [zớ-rît] "head-pl.”, [zứ títá-lí] "big head-sg."

c. /pág-gá/ [pá -á] “woman-sg.” cf. [pá?-bá] "woman-pl.” [pà?-sár-lị̂] "spinster-sg."

$4 \quad$ While there is no doubt that the underlying forms of surface [?] has a dorsal place of articulation, determining whether it is $/ \mathrm{k} /$ or $/ \mathrm{g} /$ is not always easy. The most reliable source of evidence is sister Gur languages, especially Mampruli. The level of intelligibility of each language to speakers of the other is very high as they have $98 \%$ lexical similarity. Mampruli is considered by some Dagbani speakers a dialect, not a separate language. For instance, the underlying forms in (12) $\mathrm{a}-\mathrm{b}$ are the surface forms of the same words in Mampruli. The use of Mampruli forms to determine the voicing of the underlying velar plosives is based on the assumption that some of these changes are diachronic in nature. Thus, it is very likely that the Mampruli forms were present in a common ancestor language. 
Hudu, F./ Asymmetries in the phonological behaviour of Dagbani place features d. /kób-gó/ [kób-gó] "hair-sg.” cf. [kób-rí] "hair-pl.”, [kòb pèl-lí ] "white hair-sg."

Each noun in (12)a-c contains an underlying ambi-morphemic geminate $/ \mathrm{g} /$. The root has a dorsal as coda; the suffix also has a dorsal as onset. Evidence for this comes from the nouns in (12) $\mathrm{d}$ and (13) below, which lack these geminates. The nouns in (12) $a-b$ belong to the same nominal class as those in (12)d and (13). This sameness of nominal classification is determined using the sameness of singular and plural suffixes /-go/ and [-ri] respectively (see Olawsky, 1999; Miehe, 2012; Hudu, 2005, 2014b). The only reason for deletion taking place in (12)a-b but not in (12)d or (13) is that, in the latter, there are no geminates in the underlying forms.

(13) Debuccalisation only: $\left(/ \mathrm{g} / \rightarrow[\mathrm{P}] / \mathrm{V}_{\ldots}, / \mathrm{k} / \rightarrow[\mathrm{?}] / \mathrm{V}_{-}\right)$

a. /dà-gú/ [dà-?ú] “wood-sg." cf. [dà-fí] “wood-pl.” [dà dzí-hí] "short wood-pl."

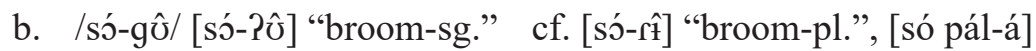
"new broom-pl."

c. /mó-gú/ [mó-?ớ] “grass-sg.” cf. [mó-rí] “grass-pl.”, [mò kưm-á] "dry grass-pl."

d. /kpíkpá-gớ/ [kpíkpá-?ớ] “catfish” cf. [kpíkpá-fí] “catfish-pl.”, [kpíkpá bíl-á] "small catfish"

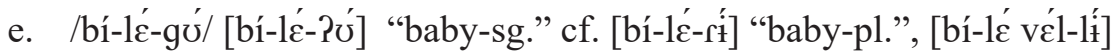
"beautiful baby"

On the one hand, while the lexical roots in (12) have CVC structure, those in (13) have a CV structure. In the two datasets being compared, the compound forms provide evidence that the nouns in (12) have an underlying / CVg-gV/ structure, and that the surface [CVPV] forms are due to a deletion of either the root coda or the suffix onset. On the other hand, having established sameness of the nominal classification between the two datasets, the singular and plural forms in (13) provide evidence that it is the root-final stop, not the suffix onset one, that is deleted. The forms in (13), 
which also have surface [CV?V] structure in singular forms have $\mathrm{CV}$ roots. The compounds provide the evidence.

Degemination in Dagbani applies asymmetrically because non-dorsal geminates in similar environments are not affected. Geminate coronals and labials are illustrated in (14) below.

(14) No degemination for coronal and labial geminates

a. gbál-lị “grave-sg.” gbál-á “grave-pl.” gbál kưr-lí "old grave-sg."

b. wơl-lị "branch" wól-á "branch-pl.” wơl dzí-hí "short branch-pl."

c. jél-lí “issue-sg.” jél-á “issue-pl.” jèl bí-hí "small (minor) issue-pl

d. kpíl-lí “(fruit) seed-sg.” kpíl-á “seed-pl.” kpìl-sábín-lí "black seed-sg."

e. láb-bô "return-nom." làb[ì] "return.V" làb-já "return-perf."

f. kób-bû "infect-nom." kòb[ì] "be infected” kòb lí "get infected with"

g. fع́b-bô "whip-nom." fèb[i] "whip.V” fèb-rá "whip-imperf.

\section{Debuccalisation}

Debuccalisation is a term used to describe any phonological process that results in the loss of underlying oral constriction of a segment. In Dagbani and many languages, it targets coronals and dorsals, making them glottals. What makes the change a case of lenition is that, in the production of a glottal stop, the vocal cords are not able to assume a stricture that can produce fortis sounds. In addition to degemination, the data in (12) illustrate debuccalisation of dorsals, as do the data in (11), (13) and (15)a-b below. The debuccalisation of $/ \mathrm{s} /$ is also illustrated in (15), where it becomes $[\mathrm{h}]$ in underlying $\mathrm{CV}: \mathrm{sV}$ words. 
Hudu, F./ Asymmetries in the phonological behaviour of Dagbani place features

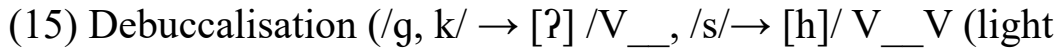
syllable)).
a /lớg-r'́/ [ló?-lít
"side-sg."
b /sàkì/ [sà̀ì]
"be sufficient"
c /má:sílí/[máhílít]
"cool weather after rain" (c.f. mà:sím "the state of being cool")
d /nè:-sì̀ [nغ̀-h̀̀] "awaken-pl." (c.f. nè:-sîm "the state of being awake/clear")
e /mó:sî̀ [móhî̀] "become reddish" (c.f. mò:-sîm "reddishness")
f láná:sí/ [ánáhí] "four"
g /bìsím/ [bìhím] "milk"
h /bí:-sí/ [bí-hí] "children"
i /bo:si/ [bóh[1̂̃]] "ask"

In (15), coronal debuccalisation takes place along with the shortening of the preceding vowel. The related words in (15) c-e provide synchronic alternations that support the presence of underlying long vowels. Further evidence also comes from Mampruli, in which all the underlying forms in (15) surface. This loss in oral constriction is blocked when $/ \mathrm{s} /$ is an onset of a heavy syllable, in words with CV:sim structure. Given that neither vowel shortening nor $/ \mathrm{s} /$ debuccalisation takes place without the other, in forms with the nominalising suffix -sim, vowel shortening is also blocked. This is further illustrated in (16) d-e. This is not the case for dorsals, as they debuccalise in onset positions of CVC syllables as well, (16)a-c. ${ }^{5}$ Labials, on the other hand, maintain their stricture in intervocalic position, as already shown for geminate labials in (14). Further examples are shown in (16)f-j.

5 Analysis of why both /s/ debuccalisation and vowel shortening take place or fail to take place is beyond the scope of this paper. Given that the dorsals and labials do not follow a long vowel, this specific case does not present a perfect asymmetry between dorsals and the other place specifications. Unlike the coronal, there are no CV:bVC nor CV:gVC that would make it possible to explore a perfect asymmetry. When the dorsal occurs in a CV:gV, it deletes optionally, as already illustrated in (10). 
(16) Asymmetric application of debuccalisation to dorsals, coronals and labials.

Underlying dorsals: debuccalisation applies.
a dó.rím
"relative",
b sà.?ł̀m
"spoil",
c là.?̀̀m
"gather"

Underlying coronal: debuccalisation fails.

d bì:-sîm "hot-nom. (heat)"

e tò:-st̂m "able-nom. (wherewithal)"

Underlying labial: debuccalisation fails.

f dàbêm "fear"

g ta:bó "timber"

h nápón-á "foot-pl."

i dàpál-bá "offspring-pl."

j tàpá?-á “cheek-sg."

From a phonological perspective, the debuccalisation of $/ \mathrm{s} / \rightarrow[\mathrm{h}]$ may not be assumed to constitute lenition, both sounds being fricatives. From an articulatory perspective it does constitute lenition, given that $[\mathrm{s}]$ has a stronger stricture than $[\mathrm{h}]$. Moreover, this change is of relevance to the discussion here because of the change in place specification that results from it. At the same time, the fact that $/ \mathrm{s} /$ and other coronals are preserved as coronals in some intervocalic positions means that the application of debuccalisation is asymmetrical. It always targets dorsals, it does not always target coronals and it never targets labials. What is more, unlike plain dorsals, debuccalisation does not define the overall distribution of coronals, as [s] and other coronals surface in intervocalic positions. 


\section{Spirantisation}

Spirantisation also targets $/ \mathrm{k}, \mathrm{g} /$, and no other consonants, reducing them to affricates. This is more prevalent in loan words with the dorsal as an underlying final segment. The underlying forms of the Hausa words shown in (17) below are based on the dialect of Hausa spoken in Ghana, which is the source of the loans.

(17) Spirantisation (/g, k/ $\rightarrow[\mathrm{d}, \mathrm{g}] /$ front vowels).
a. bá:dłî
"a bag for clothing" (< English)
b. gándłî
"a gang" ( $<$ English $)$
c. màlítfí
"A personal name" $<$ [malik] "king" (Arabic)
d. móltyi "subjects" $<$ [mulk] "Authority/sovereignty" (Arabic)
e. àlàhìtfí "sin" < alhaki (Hausa) < Pal haq "the right" (Arabic)
f. dźílímá "respect" < [girima] "respect" (Hausa)
g. tgiritîi "valuable" < [kiriki] "worth" (Hausa)
h. mátfélé "bicycle" < [makeri] "blacksmith" (Hausa)

It is important to note that the palatal articulation manifested in spirantisation shown here affects many consonants in Dagbani. It is not only triggered by a word-final epenthetic [i] in loans but front vowels in any context, as discussed in Hudu $(2010,2016)$. Other consonants affected include $/ \mathrm{y}, \mathrm{s}, \mathrm{z} /$, which surface before front vowels respectively as $\left[\mathrm{n}, \int, 3\right]$. However, of the five consonants affected, the only consonants whose surface realisations constitute lenition are $/ \mathrm{g}, \mathrm{k} /$. The dorsals are also the only consonants which lose their place specification when palatalised. Indeed, the fact that front vowels are the triggers means that the surface form of any palatalised consonants is coronal, regardless of its underlying place specification.

\section{Fortition}

In stricture terms, fortition produces a result directly opposite that of lenition as far as the surface distribution of place features is concerned. While lenition may lead to the loss of place 
features, fortition in Dagbani does not lead to the emergence of place features in contexts where they are absent underlyingly. However, the enhancement that is given to affected segments guarantees the presence of place features associated with these segments.

There are two observed patterns of fortition in Dagbani. In one process, we get an affricate from a fricative before back vowels in the Nanuni Dialect (/z/ $\rightarrow[d]])$. For some speakers of Nanuni, [d] surfaces in all contexts, ruling [z] out of the dialect entirely.

(18) Stopping in the Nanuni Dialect $(/ \mathrm{z} / \rightarrow[\mathrm{d}] / /$ [back vowels])

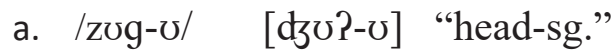
b. /zon-a/ [d]on-a] "bat-pl."
c. $/ z \circ m /$ [ḑom] "blind.sg"
d. /zo/ [dzo] "move away"
e. /zo-ja/ [dzo-ja] "mountain-pl."

The other process of gemination targets labials. Gemination of [m] happens optionally in word-final positions and before the second or third person clitics /a, o/. When the nasal geminates, it becomes tone-bearing and syllabic, producing three syllables. When it does not geminate, it is realised as an onset to the following vowel, producing only two syllables. In (19), syllable boundaries are marked.

(19) Labial gemination

a. /là?m/ [là.?m̀:. ó] / [là?.m ó] "meet her (a euphemism for sexual intercourse)"

b. /sà?m/ [sà.?m̀.. á] / [sà?.m á] "spoil you"

c. /jóhm/ [jó.hḿ:. á] / [jóh.má] "deceive you”

d. /bèhm/ [bè.hm̀.. ó] / [bc̀h.m ó] "doubt him/her"

e. /tyilm/ [tgíllḿ.. ó] / týl.m ó] "delay him/her"

Gemination is also observed in other contexts. For instance, 
/b/ becomes a geminate in the plural suffix "-ba" when the suffix attaches to the root for man (/dó-j́/ [dó-ó] "man-sg." [dó-bbá] "man-pl." [dò tó̂́y-gú] "weak man-sg." (Eastern Dialect)). There are also ambisyllabic coronal and labial geminates resulting from morphological concatenations, as already demonstrated in (14) and repeated in (20).

(20) Coronal and labial geminates

Coronal

a. gbál-lí “grave-sg.” gbál-á “grave-pl.” gbál kúr-lí "old grave-sg."

b. wơl-lí "branch-sg." wơl-á "branch-pl.” wòl dłí-hí "short branch-pl."

c. jél-lí “issue-sg.” jél-á “issue-pl." jèl-bí-hí "small (minor) issue-pl

d. kpíl-lí “(fruit) seed-sg.” kpíl-á "seed-pl.” kpíl-sábín-lí "black seed-sg."

Labial

e. láb-bô "return-nom." làb[i] "return.V" làb-já "return-perf."

f. kób-bô "infect-nom." kòb[i] "be infected" kòb-lì "get infected with it"

g. féb-bô "whip-nom." fغ̇b[i] "whip.V" fèb-rá "whip-imperf.

In both patterns of fortition, the place specification of the underlying forms, coronal (18); (20)a-d or labial, (19); (20)e-g is maintained. The asymmetry observe is this: whereas phonological processes are triggered to block germinate dorsals in contexts where they would otherwise have occurred underlyingly, coronal and labial germinates are permitted to surface either as a product of the phonology proper or due to a morphological concatenation. 


\section{Summary on segmental strength phenomena and markedness generalisations}

The observed patterns of fortition and lenition affect three of the distinctive place features: labials, coronals and dorsals. Every process of lenition that affects the place specification of consonants targets dorsals. It either replaces it with another place feature (as in debuccalisation and spirantisation) or eliminates it from surface form (as in deletion). The consequence is that the dorsal has a lesser number of contexts where it can surface. It is lost in intervocalic positions (e.g. /páká/ [pár-á] "woman-sg.") and post-vocalic positions (e.g. /jág-lî́/ [já?-lî̀] "side-sg."). Its distribution is limited to initial position of lexical words, after consonants (e.g. dàmgì "squat", tábgî "kick") and non-lexical units that are preceded by consonants (e.g. tùl-gâ "pestle"). By contrast, not only do coronals and labials surface in the very contexts where dorsals are lost, their presence in those contexts is also enhanced through gemination.

The asymmetry provides a window for deriving a markedness conclusion given the observation that unmarked segments tend to occur in more positions than marked segments (Battistella, 1990; Waugh \& Lafford, 1994; Trubetzkoy, 1939/1969; Hockett, 1955; Greenberg, 1966; Stemberger, 1992). If the goal of place-changing lenition processes is to regulate the overall distribution of sounds, a more marked place is likelier to be lost in many positions through lenition while a less marked place feature will only likely get lost through lenition in fewer positions. It is important to note that the loss of the place feature through lenition by itself does not produce evidence for a markedness distinction. The important markedness distinction is the result of that loss on the overall distribution of sounds with various place specifications.

When this distributional diagnostic of markedness is applied, we end up with the dorsal as the most marked place. Unlike plain dorsals, labial-dorsals do surface in intervocalic positions of simplex nouns. 
(21) Labial-dorsals in intervocalic positions
a. dàgbán-â "A Dagomba person-sg"
dàgbán-lí
"The Dagbani language"
b. àkpà?là
"fever accompanied by rigor" (Western
Dialect)
c. nàkpà-á
"portion of farmland-sg."
d. kpàkpí-jâ
"tortoise-pl."
e. sàgbò-ó
"small calabash bottle-sg." (Naden, 2014)
f. bờkpàhá
"wizard"

\section{Contrast neutralisation and other phonological processes}

In addition to their asymmetrical behaviour with regard to the effects of stricture-changing phonological processes, place features are also at the heart of phonological neutralisation phenomena, harmony, assimilation and coalescence. In this section, these processes and their markedness implications are discussed.

When neutralisation is a product of phonological processes, it provides a markedness diagnostic, as noted by Trubetzkoy (1939/1969) and featured in many subsequent studies (e.g. Jakobson, 1941; Greenberg, 1966; Cairns, 1969; Paradis \& Prunet, 1991; de Lacy, 2006). These studies present two views on the markedness conclusions that can be drawn using the output of neutralisation. On the one hand, in many patterns of neutralisation, the goal is to suppress the marked and allow only the unmarked to surface. On the other hand, due to the need to maintain contrast in language, surface forms of some patterns of neutralisation may be more marked than the forms that fail to surface. De Lacy's formulation of the former observation is shown in (22).

(22) Neutralisation output as a markedness diagnostic (de Lacy, 2006, p. 28)

If $/ \alpha /$ and $/ \beta /$ undergo structurally conditioned neutralisation to output $[\alpha]$, then there is some markedness hierarchy in which $[\beta]$ is more marked than $[\alpha]$. 
The latter observation is known as the principle of markedness preservation or the submergence of the unmarked, (de Lacy, 2006; Rice, 2007), stated in (23).

(23) Preservation of the marked (de Lacy, 2006, p. 1)

There is a grammatical pressure to preserve marked elements. If $\mathrm{x}$ is more marked than $\mathrm{y}, \mathrm{x}$ can be unaffected by a process while $\mathrm{y}$ is forced to undergo it.

The main observation behind the principle of "preservation of the marked" is that, marked units need to be preserved in some contexts to ensure contrast. If languages were to permit only unmarked segments in surface forms, there would be very few words in languages, which would make it difficult to realise differences between languages. Even within one language, there would be insufficient sub-lexical units to form words enough to express the wide variety of concepts that speakers need to express. Below, nasal place assimilation and its markedness implications are discussed.

\section{Nasal place assimilation}

Previous studies (Olawsky, 1999; Hudu, 2014b etc.) show that nasal place assimilation (NPA) is widespread in Dagbani and results in the neutralisation of the underlying contrast between the five phonemic nasals in the language $/ \mathrm{m}, \mathrm{n}, \mathrm{ym}, \mathrm{n}, \mathrm{y} /$. Distributionally, $/ \mathrm{n}, \mathrm{ym} /$ are only contrastive in word-initial positions. There are no words with underlying palatal or labial-dorsal nasals in non-initial position. An important generalisation on NPA in Dagbani that is of interest to the discussion in this paper is that, NPA targets bound morphological units, including nominal roots, clitics and affixes. When a nasal surfaces in a final position of any of these units, it becomes a target of NPA, taking on the place specification of the trigger. This contrasts with free morphological units such as inflected nouns and verb roots. In (24)a, NPA is shown affecting a nasal cardinal prefix. In (24)b, it affects a reduplicant and pseudoreduplicant prefix. In (24)c, it affects the possessive and infinitive nasal proclitics. 
(24) NPA in bound morphological categories: Affixes and clitics.

a. n-dà:m "one" y-wóí "nine” n-jí "two"

b. zưn-zư-lí “maggot-sg." pưm-pónó “right now” gbínm-gbán "elephant grass"

c. n sám-lị̂ "my debt-sg." y jơb[ì] "to chew" $m$ bá "to ride"

The data in (25) show the effects of NPA on final nasals of bound nominal and adjectival roots. In all these words, the underlying place specification of the nasal is determined when the root takes a vowel suffix, as shown in all the plural forms in (25) a-c and both singular and plural forms in (25)d-e. Where the nasal is followed by a CV suffix or another lexical root in a compound word, the nasal assumes the place of the following consonant.

(25) NPA in bound morphological categories: Bound nominal/ adjectival roots.

Singular forms Plural forms Compound forms
a. gbí?ín-lí
gbí?ím-á gbìììn nám-á "female lion-pl”
b. sálín-lí
sálím-á sàlìn kứ-lí “old gold-sg.”
c. zón-gá [zón(a)]
zón-á
zòm bí-hí "small bat-pl.”
d. bín-ît
bín-â

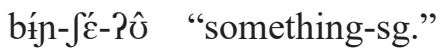
e. dón-í
dơn-á
dù:m bí-á
"knee child-sg. (knee cap)

There are two aspects of NPA in Dagbani that have not been noted in previous studies. First, while an underlying coronal is always a target, an underlying dorsal place is never a target of NPA in Dagbani. The data in (26) illustrate the asymmetric behaviour of dorsals. 
(26) No NPA with underlying dorsal nasals. ${ }^{6}$

\section{Singular Plural}
a. sán-lí
sán-á
"span"
b. saykay-lí
saykay- á
"name of a plant-sg."
c. pón-lí
pón-á
"British Pound-sg"
d. mày-lí
mày-á
"genuine-sg."
e. tín-lí
"lower end"

The second observation is that, unlike the coronal place, the labial place is not always a target. In contrast to the data in (25)a-b, those in (27) show that $/ \mathrm{m} /$ resists NPA. The lack of any obvious differences between (25)a-b and the data in (27) is at the heart of the analysis here. In other words, $/ \mathrm{m} /$ is not a systematic target of NPA. Sometimes it is targeted, sometimes it is not. There is no way to determine when it gets targeted and when it does not.

(27) No NPA with underlying labial nasals.

Singular Plural
a. sám-l̂̂t
sám-â
"debt"
b. sím- lí
sím-á
"groundnut"
c. kàm-lí kàm-á
"garden egg"
d. gàm-lí gàm-á
"door"
e. ním-dî̀ ním-â
"meat"
f. nám.dí-lí nám.d-a
"footwear"
g. gừ-dí
"cotton"

The failure of NPA in (26) presents a pattern that is the exact opposite of what has been noticed so far. Dorsals are preserved in a context where labials and coronals are lost to neutralisation. What

\footnotetext{
6 I do not have data with suffix-initial [t] or [d] to include in (26) and (27). I do have such examples in verb morphology, (e.g. mòn-dì “deny-ing”). However, in verbs, all root-final nasals maintain their underlying place specification because, unlike nouns, the verb roots are free forms. Thus, verbs are not the right examples for the analysis. Nominal suffixes with initial [d] seem relatively rare in Dagbani.
} 
is more, it suggests a gradient asymmetric pattern: with dorsal never targeted, labials sometimes targeted, and coronals always targeted. The implication of this for markedness is discussed shortly. The next section looks at coalescence.

\section{Coalescence}

In a subdialect of the Western Dialect, spoken mainly in a village called Tolon, /g/ coalesces with a /s/ to produce $[\mathrm{x}]$. The dorsal loses its stricture but maintains its place specification. The coronal maintains its stricture but loses its place specification.

(28)Dorsal-coronal coalescence in Tolon subdialect. $(/ \mathrm{g}+\mathrm{s} / \rightarrow[\mathrm{x}])$.
a. /tògsì̀ [tòxì]
"speak"
b. /nàgsím/ [nàxím]
"delight/sweetness"
C. /zàgsì/ [zàxì]
"refuse"

A sequence of $\mathrm{a}[\mathrm{b}]$ and /s/ does not coalesce into one segment, (29). Thus, no place specification triggers a change in the place of a contiguous segment in a non-assimilatory way except the dorsal.

(29) No labial-coronal coalescence.
a. sàbsì-?ú
"wall gecko-sg."
b. gàbsì
"stain"
c. tób-sím
"heavy-Nom. (weight)"
d. pòbsì
"blow air with the mouth"

\section{Implications for markedness}

From a markedness perspective, the asymmetry in the application of NPA to place features is interesting, considering previous observations on preservation of the marked which applies mainly in patterns of assimilation that result in contrast neutralisation. For instance, studies on Korean (Iverson \& Kim, 1987; Cho, 1988; Avery \& Rice, 1989; Rice, 1994) show that Korean coronals are targets of regressive place assimilation and labials assimilate to velars, but labials and dorsals do not assimilate 
to coronals. Thus, while coronals are always targets when any other place feature is the trigger, dorsals are never targets of assimilation. Labials lie between these two poles, as they are only targets when the trigger is a dorsal. While every place node can trigger NPA in Dagbani, the asymmetry bears some resemblance with the Korean pattern with respect to which place feature can be a target. In both languages, dorsals are never targets, coronals are always targets, labials are only targeted sometimes, not always.

The $(/ \mathrm{g}+\mathrm{s} / \rightarrow[\mathrm{x}]$ coalescence is a case of preservation of the marked, similar to the resistance of the dorsal to NPA. It points solely to the dorsal as more marked than the coronal. An alternative surface form such as [d] is not realised. The emergence of [d] would be predicted given that such an outcome would have resulted in maintaining the existing sounds in Dagbani phonology. Unlike /d/, [x] only surfaces in this subdialect and only as a product of coalescence between $/ \mathrm{g} /$ and $/ \mathrm{s} /$.

\section{Backness harmony and the emergence of labial-dorsals}

There are two patterns of backness harmony triggered by the high central vowel $/ \dot{\mathbf{i}} /$ and targeting only back vowels. In the first pattern, back vowels lose their backness in harmony with a derivational suffix / $/ \dot{\mathbf{i}} /$. This is shown in (30), where the surface forms of the singular nouns on the left column result from nasal place assimilation and deletion of the final vowels.

(30) Back vowels harmonise with suffix $/ \mathbf{i} /$.

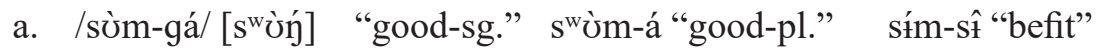

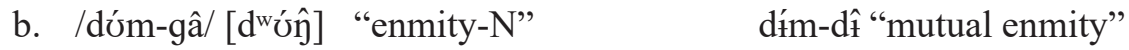

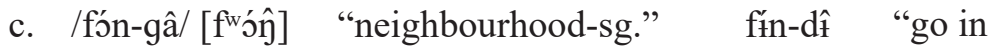
different directions"

In the second pattern, back vowels surface as [i] in grammaticalised forms such as those in (31). In such words, which are unique to the Eastern Dialect, lexical roots are reduced to prefixes. In addition to the loss of backness, onset dorsals also 
Hudu, F./ Asymmetries in the phonological behaviour of Dagbani place features become labial-dorsals through labial insertion or spreading from the vowel.

(31) /u, $v /$ reduction in grammaticalised forms (Eastern Dialect)

a. kưl-gá "river-sg." /kwờl-kpán-gá/ [kpìl-kpáyá] "river side” (A village name)

b. kưl-gá "river-sg." / / kº̛̀l-kpínt̂/ [kpìl-kpínt̂] River Dakar (a river in Yendi)

c. kưl-gá "river-sg." /kwòl-dłínî/ [kpìl-dzínî] (Name of a village)

d. gưn-gá "kapok tree-sg." /gwò̀n-tínlî̀/ [gbìn-tínlî̂] “down a kapok tree" (A suburb of Yendi)

e. dù-ú "room-sg." /dwò-kpín-í/ [dì-kpín-í] "wall of a room”

f. zứg-gư "head-sg." /zwớ? píl-gứ/ [zí píl-gơ] "head cover-sg. (hat)"

In similar compound forms that are neither grammaticalised nor lack the central vowel in the second syllable, the back vowel in the first syllable does not lose its backness.

(32) No /u, $v /$ reduction in grammaticalised forms

a. kưl-gá / $/ \mathrm{k}^{\mathrm{w}}$ ùl-nó-ô/ *[kpìl- nó-ô] "river chicken" (black cuckoo)

b. kưl-gá /kwòl-nó-lî̀/ *[kpìl- nó-lị̀] “river mouth” (river bank)

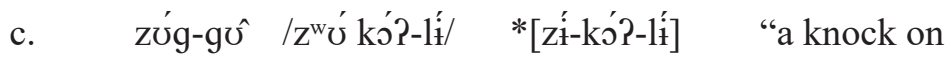
the head with the knuckle"

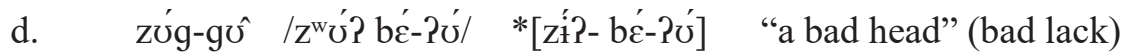

e. gưn-gá /gwờn-dó-?ứ/ *[gbìn-dó-?ú] "Name of a village"

f. gưn-gá /gwìn-ká-á/ *[gbìn-ká-á] "kapok-leaf soup"

The processes in (31) relate to the reference in previous discussion relating to positional effects in phonological patterns and illustrated in (5) and (6). Having been reduced to prefixes, the roots in the words on the left column in (31) become weak positions, making 
them a domain for possible neutralisation of underlying segmental contrast. Under the feature theory assumed here, any [+back] $\rightarrow$ [-back] change constitutes a loss in dorsal place given that back vowels are [+dorsal], as back vowels are featurally complex labialdorsals (Ohala \& Lorentz, 1977). Of the two contrastive place features, [dorsal] and [labial-dorsal], that are potential targets of neutralisation in the two datasets, only underlying labial-dorsals /o, $\mho /$ are simplified into placeless central vowel /í in both (30) and (31). This may serve as the basis to tentatively conclude that the harmony is a case of structure simplification where $[\sigma, 0]$ become simple with the loss of both dorsal and labial features. It is also a case of the emergence of the unmarked (McCarthy \& Prince, 1994), as previous researchers (e.g. Hudu (2010) show the vowel [i] to be the default, unmarked vowel in Dagbani).

Of overriding interest to the discussion in this paper is the fact that the data in (30) and those in (31) present two patterns of neutralisation: one between two contrastive vowels $(/ \mathrm{\mho} /$ and $/ \mathbf{i} /)$ and another between two pairs of contrastive consonants $(/ \mathrm{k} /, / \mathrm{kp} /)$ and $(/ \mathrm{g} /, / \mathrm{gb} /)$. In both (30) and (31), a structurally complex back vowel is simplified as $/ \mathbf{i} /$. In (31), there is an apparent pattern that is the exact opposite of what may be taking place in (30): simplex plain dorsals (/k/, /g/), surface as complex labial-dorsals (/kp, / $\mathrm{gb} /$ ). This raises a question about analysing the harmony as a case of simplification of a complex segment. If the $/ \mho / \rightarrow[i]$ change is merely a case of complex structure simplification, why should the same change in (31) be accompanied by the surfacing of a complex labial-dorsal consonant?

What is consistent in both (30) and (31) is an apparent avoidance of a dorsal feature, not the labial or labial-dorsal. In (30), the labial feature is only an accidental target along with the targeted [+back/dorsal] feature. This is because the loss of backness/dorsality alone in the back vowels would have resulted in the surfacing of the front rounded vowel [y], which is not part of Dagbani sounds. Thus, to preserve the structure of Dagbani sounds, the deletion of the $[+$ back] also results in that of the [+labial] feature. The vowel 
[i] that is left behind is neither back nor front. It is a central vowel.

The change from $/ \mho / \rightarrow[i]$ in (31) is also dictated by the need to preserve the underlying inventory of Dagbani sounds. Thus, $[\mathrm{y}]$ is blocked from surfacing. However, there is also the emergence of a labial in the onset to the vowel, producing a complex labialdorsal. This is the most crucial part of the data, as it shows a clear disparity between what is seen in (30) and what takes place in (31). While the [Labial] is lost in both datasets, it is only in (31) that the loss of the labial feature also results in a concomitant gain in a labial feature in the onset. Such a compensatory gain in (30) would have produced labial coronals $[\mathrm{db}]$ and $[\mathrm{sp}]$. Of these, only [db] is attested in Dagbani, and that too only as a variant of $/ \mathrm{gb} / \mathrm{before}$ front vowels. Thus, the failure of [db] and [sp] to surface in (30) is dictated by the same consideration blocking the surfacing of [y] in both (30) and (31): structure preservation.

The two processes observed here, viz the surfacing of a labial feature in the onset and the loss of same in the back vowels in (31) are not expected to take place under an analysis that the simplex labial or complex labial-dorsal is the target of the neutralisation. If it were the case that the language treats $[\sigma]$ as a marked sound due to its complexity as a labial-dorsal, and for that reason forces it to neutralise with $[\dot{i}]$, the $/ \mho / \rightarrow[\dot{i}]$ change would not have taken place at the same time as another change resulting in the surfacing of a labial-dorsal. The only alternative viable explanation is that, it is only the dorsal feature that is the target for loss in the $/ \mathrm{v} / \rightarrow$ [i] change and this happens because the dorsal is more marked. In the same way, the underlying plain dorsals surface as labialdorsals because the dorsal feature is relatively more marked than the surface labial-dorsal.

It is also important to note that the surfacing of [kp] and [gb] in (31) is unlike the failed emergence of [y], which is dictated by structure preservation. The loss of a labial feature in the back vowels with no surface labial-dorsal would produce licit [gi] and [ki] sequences. Just as the underlying coronals in (30) remain coronal when the $/ \mho, \mathrm{o} /$ become $[\dot{\mathrm{i}}]$, the dorsals in (31) could also remain 
plain dorsals as onsets of [i] in the surface forms. The surface forms would resemble existing words such as gíl'́t "go around", and kìmsì "tighten". These two words have minimal pairs gól' "wait" and kìmsì "cause someone to cry". This means that there is nothing in the phonology of Dagbani compelling the change from plain dorsal to labial-dorsal.

It is worth noting that two processes in (31) resulting in the surfacing of $[\mathrm{kp}, \mathrm{gb}]$ are also confirmed in Dagbani loanwords, some of which are noted below.

(33) $/ \mathrm{k}, \mathrm{g} / \rightarrow[\mathrm{kp}, \mathrm{gb}]$ in loans
a. kpínmkpá:mbá
$<$ Konkomba
"people of Konkomba ethnicity"
b. kpà:kṕ́ló
$<$ ka:kulo
"fried mashed plantain" (Ga)
c. àtàkpá:má
$<$ Ata Kwame
"mud house" (Akan)
d. kpákpâ
$<\mathrm{k}^{\mathrm{w}} \mathrm{ak}^{\mathrm{w}} \mathrm{a}$
"coconut/palm nut" (Hausa)
e. gbí dzó:
$<$ gud dzob
"good job" (English)

The phrase in (33)c contains the names Atta and Kwame, which are regular personal names in Akan. The Akans reportedly nicknamed mud houses after an Ivorian called Atta Kwame, reputed to have invented or popularised that style of building in Ghana. Borrowed into Dagbani, the $\left[\mathrm{k}^{\mathrm{w}}\right]$ in Kwame has changed into a labial-dorsal, in spite of the fact that labialised [k] preceding round vowels is the norm in Dagbani (e.g. kº́?-ช́ "antelope-sg."). In fact, the name Kwame itself is pronounced in Dagbani (as a loan from Akan) without a surface [kp]. The $/ \mathrm{k}^{\mathrm{w}} / \rightarrow[\mathrm{kp}]$ change is also observed in (33)d. The phrase in (33)e is the only one that is not part of the regular lexicon of Dagbani. It is a funny repetition of the English phrase "good job" made by a girl under two years (with virtually no exposure to English) who was being praised for following instructions well. It may not be an indication that the child could not articulate the dorsal. It is a confirmation of the observation made about adult phonology to the effect that a $\mathrm{CV}$ sequence in which both consonant and vowel are dorsal is very marked and becomes a target of asymmetrical neutralisation. In this girl's phonology, the 
[kpi/gbi] sequence was definitely acquired before a dorsal [ko/go] sequence.

It is also worth noting that $[\mathrm{kv} / \mathrm{gv}]$ and $[\mathrm{kpi} / \mathrm{gbi}]$ are contrastive sequences in the Western Dialect, but not always so in the Eastern and Nanuni dialects. Thus, many words with underlying [kv/go] sequences are pronounced as $[\mathrm{kpi} / \mathrm{gbi}]$, especially in the Eastern and Nanuni dialects. This is yet another indication of the marked position of the dorsal place feature. The words in (34)b-f are sourced from Naden (2014).

(34) Dialectal differences in (labial)-dorsal onsets with back vowels Western Dialect Eastern Dialect

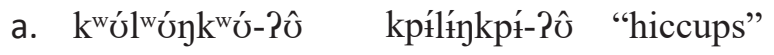

b. kwờlkpár-gá kpìlkpá $\mathrm{e}$-gá "fairy, bush sprite"

c. kº̛̀kpál-gá kpìkpál-gá "the fan palm”

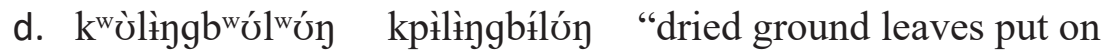
sore for healing"

e. kpº̛̀nkàyá kpì̀nkpàná "forearm.sg."

f. tł̀k ${ }^{w}$ òblá:kwớm tìkpł̀blá:kpím "Cassia occidentalis.sg."

However, this does not mean that the $[\mathrm{kv}]$ and $[\mathrm{gv}]$ sequences are illicit syllables in any dialect. In all dialects, there are words with $[\mathrm{kv}]$ and $[\mathrm{gv}]$ sequences where the dorsals remain plain dorsals. Examples are shown in (35).

(35)Underlying $[\mathrm{kv}]$ and $[\mathrm{gv}]$ sequences surfacing as such in all dialects
a. kứlớnkứ-â
"name of a beetle-like insect-sg."
b. kứnkơn-â
"a hillock-pl.",
c. gứlóngớm-á
"Nauclea latifolia tree-pl." (Naden, 2014)
d. gứmántyú-?ú
"chameleon-sg.".
e. gư-jâ
"cola nut-pl." 
f. kúl-gá "river-sg."

In addition to the realisation of back vowels as [i] being a dialectal tendency and not a strict rule in any dialect, it also seems to point to an active language change in progress that favours labialdorsals, against plain dorsals, particularly so because the surfacing of labial-coronals shown in (31) is more prevalent among younger speakers. While the labial-dorsal forms are produced and accepted by speakers of all generations, one speaker in her late 60 s refused

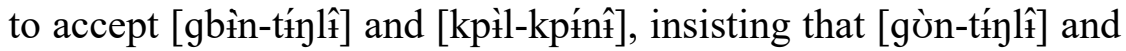
[kòl-kpínt̂] are the only accurate forms. By contrast, there are many young speakers who find it surprising when it is pointed out to them that the underlying forms are actually [gơn-tínlî̀] and [kòl-kpínî]. There is also the possibility that the surfacing of labial dorsal before back vowels is part of the diachronic changes that distinguish Dagbani from its closest Gur relatives, with languages like Gurene maintaining what may have been underlying plain dorsals in a common ancestor. For instance, the Mampruli word kolin "remain/ left over" is kpàlìm in Dagbani. Gurene, in particular, differs markedly from Dagbani in this respect, as the data in $(36)$ show. The Gurene data are from Dakubu et. al. (2007).

(36) Dorsal onsets in Gurene and their corresponding labial-dorsals in Dagbani

\section{Gurene Dagbani}
a. kươ
kpáń
"guinea fowl.sg"
b. koləgə
kpál-gô
“dawadawa spice-sg."
c. kəorey
gbár-gư
"crippled person-sg."
d. gogese
gbá?ísî
"nod head in agreement"
e. goyว
gbàý/gbòń
"skin/animal hide.sg."
f. gog $\varepsilon$
gbá?í
"shiver/shake (esp. due to cold)"
g. kõlekoka
kpíkpá-?ơ/kpớkpó-?ơ “catfish-sg.” 
With the generalisation that when two contrastive segments neutralise in a certain context the output is the unmarked one, (22), labial-dorsals should not surface as they do in (31) - (34) if complex $[\mathrm{kp}, \mathrm{gb}]$ are more marked than simplex $[\mathrm{k}, \mathrm{g}]$. Given what is attested, the only alternative conclusion is the exact opposite: that the plain dorsals $[\mathrm{k}, \mathrm{g}]$ are more marked than the labial-dorsals $[\mathrm{kp}$, $\mathrm{gb}$. In effect, we would conclude that a simplex segment (with one place of articulation) is more marked than a complex segment that combines the place feature in the simplex segment with another feature. Such a conclusion runs contrary to an overwhelming body of literature from diverse theoretical persuasions which argue that complex segments are more marked than simplex ones, as already discussed.

It is important to note that the position of Dagbani plain dorsals as more marked than labial-dorsals is by no means the only case of complex segments being less marked than simplex ones. The vocoids $[\mathrm{u}, \mathrm{w}]$ are complex labial-dorsals. Yet they are less marked than their respective simplex labial and dorsal variants [u, u]. Similarly, syllables with onsets are less marked than onsetless syllables, in spite of onsets constituting more structure. At the word level, monomoraic content words are highly marked, in spite of being structurally simpler. ${ }^{7}$ However, labial-dorsal plosives differ from these complex structures when evaluated using other markedness disgnostics, especially those that are not uniquely phonological (see Rice, 2007, p. 80). Labial-dorsal plosives are less common, appear in fewer grammars, are harder to articulate and their presence implies that of plain labial and plain dorsal plosives but not vice versa. By contrast, labial-dorsal vocoids, syllables with onsets and words with a greater number of moras are more common, appear in more grammars and their presence is implied by that of their more marked variants. Thus, unlike labial-dorsals, whose markedness is predicted by many criteria, including complexity, these units are predicted by other criteria to be unmarked except their complexity.

7 I am grateful to an anonymous reviewer for pointing out this observation and the examples of complex unmarked units. 


\section{Why the emergence of labial-dorsals is not a case of assimilation or coalescence}

Two potential alternative analyses to the data on the emergence of labial-dorsals presented above, and which are rejected here, are assimilation and coalescence. There are a number of fundamental properties characteristic of an assimilatory process that are lacking in the data. First, phonetically, assimilation is driven by the desire to minimise articulatory effort by coarticulating adjacent segments with one articulatory gesture instead of two potentially contradictory gestures. The surface forms of the data under discussion cannot be said to achieve that goal. Changing a / $\mathrm{k}^{\mathrm{w}} \mathrm{U} / \mathrm{sequence}$ into [ $\mathrm{kpi}$ ] does not lead to the loss in an articulatory gesture neither does it result in any ease of articulation. In fact, as far as the relative ease of articulation is concerned, the surface form is more difficult than the underlying form, considering the extra consonantal stop gesture employed. Second, the trigger of assimilation maintains the feature it spreads to the adjacent target segment. The result of assimilation is that, in the surface form, both trigger and target share one feature. That is clearly not what is going on here, as the output forms are dissimilar.

Third, in an assimilatory pattern, the spreading of the feature from the trigger is conditioned by the presence of an eligible target. Where an eligible target does not exist, a potential trigger cannot perform the function of triggering assimilation. For instance, in English vowel nasalisation, a nasal coda spreads nasality to its nucleus (e.g. /s $\Lambda$ dən/ $\rightarrow$ [s $\Lambda$ də̃n]). However, when the schwa is not part of the word, and the nasal is syllabic, no nasal spreading can take place. Thus, the surface form will be ( $s \Lambda d n)$. This is contrary to what we see in Dagbani. The loss of the [+labial, +dorsal] features in the putative trigger $[\mathrm{u}]$ is independent of the presence of the putative target $[\mathrm{k}, \mathrm{g}]$. In the cases driven by backness harmony, the loss of the feature itself is a requirement of a regressive vowel harmony triggered by a distant segment. In no case is the loss triggered by the need to assimilate a preceding adjacent segment. That is why this loss is observed in environments where there are no preceding 
[k] or [g]. Finally, the loss of the [+labial, +dorsal] features in the back vowel cannot be said to be driven by assimilation because the default surface form is always assimilatory without that loss: $/ \mathrm{kU}$, $\mathrm{gU} / \rightarrow\left[\mathrm{k}^{\mathrm{w}} \mathrm{U}, \mathrm{g}^{\mathrm{w}} \mathrm{U}\right]$. A process that bleeds the realisation of these assimilatory forms and produces dissimilar surface forms cannot be said to be assimilatory. What is consistent in all cases, where the emergence of [i] also results in that of $[\mathrm{kp}, \mathrm{gb}]$ and where it does not, is that, the dorsal feature is dis-preferred. In some cases, it results in a surface harmony. In others, it is due to the morphological unit being a weak position; while in others it is an apparent historical change about which very little else can be said.

Analysing the data as a case of coalescence does not hold merit either. Again, the fundamental feature that two underlying segments are realised as one on the surface, with features of both UR segments present in the surface form, is lacking. The surface forms have the same number of segments as the underlying form.

\section{Summary and conclusions}

The goal of this paper has been to present phonological asymmetries affecting labials, coronals, dorsals and labial-dorsals, and the markedness conclusions that can be derived from these asymmetries. The strength of the analyses and conclusions lies in the variety of sources from which evidence have been sought. The data are based on observations rooted in synchronic sound alternations, diachronic sound change and loanword phonology. As far as the markedness dimension is concerned, the conclusion that dorsals are the most marked and coronals the least marked is not new when the comparison is restricted to dorsals, labials and coronals, though there are studies that argue against a single universally unmarked place feature and insist that markedness can only be determined on a language-specific basis (e.g. Hume \& Tserdanelis, 2002; Hume, 2003). What the paper sought to do was to demonstrate how the markedness distinctions between place specifications in Dagbani are manifested using previously established markedness diagnostics. What is new is the evidence that Dagbani complex labial-dorsal segments are not more marked than plain dorsals. A 
summary of the various sources of evidence is presented below.

\section{Evidence from relative distribution}

Evidence from synchronic distributional patterns shows that coronals and labials surface without restrictions: they surface as onsets, codas, word-initial and non-initial positions. A labialdorsal does not surface in coda positions, but surfaces as onsets in intervocalic position of simplex words. An underlying plain dorsal in coda position is lost through deletion or place-changing lenition. Thus, plain dorsals surface only in two contexts: initial and post consonantal non-initial positions. These generalisations change slightly when nasals are considered, as [y] surfaces in and maintains its dorsality in coda positions, both underlyingly and as a product of assimilation. The labial-dorsal [ $\mathrm{gm}$ ] also surfaces in codas, but only as a product of assimilation. The summary, presented in (37), accords with the dominant view of plain dorsals as the most marked, with labial-dorsals having a slight edge distributionally.

(37) Summary of distribution of place specifications

\begin{tabular}{|l|c|c|c|c|}
\hline & word-initial & $\begin{array}{c}\text { intervocalic } \\
\text { onset }\end{array}$ & $\begin{array}{c}\text { post } \\
\text { consonant } \\
\text { onset }\end{array}$ & coda \\
\hline Labial & $\sqrt{ }$ & $\sqrt{ }$ & $\sqrt{ }$ & $\sqrt{ }$ \\
\hline Coronal & $\sqrt{ }$ & $\sqrt{ }$ & $\sqrt{ }$ & $\sqrt{ }$ \\
\hline Labial-Dorsal & $\sqrt{ }$ & $\sqrt{ }$ & $\begin{array}{c}\text { only } \\
\text { nasals }\end{array}$ \\
\hline Dorsal & $\sqrt{ }$ & $*$ & $\sqrt{ }$ & $\begin{array}{c}\text { only } \\
\text { nasals }\end{array}$ \\
\hline
\end{tabular}

\section{Evidence from phonological processes}

The emergence of labial-dorsals from underlying plain dorsals, as evidenced from synchronic alternations, diachronic change and loanword phonology, provides evidence that the labialdorsal, in spite of being articulatorily and structurally more complex, is more favoured than the plain dorsal. What is more, it suggests a 
synchronic as well as a diachronic sound change in the language that may, in the future, give labial-dorsals further greater distribution than plain dorsals. The phonological processes discussed here, which illustrate several of the diagnostics unique to phonological systems for marked phonological units, are summarised in (38).

(38) Summary of phonological patterns and their markedness conclusions

\begin{tabular}{|l|l|l|l|l|c|}
\hline \multirow{2}{*}{$\begin{array}{l}\text { Phonological patterns defining a } \\
\text { marked unit. }\end{array}$} & \multicolumn{3}{|l|}{$\begin{array}{l}\text { Markedness conclusion: } \\
\text { Which place is the most } \\
\text { marked? }\end{array}$} \\
\hline & Labial & Coronal & $\begin{array}{l}\text { Labial- } \\
\text { dorsal }\end{array}$ & Dorsal \\
\hline \multirow{2}{*}{ Gets } & $/ \mathrm{J} / \rightarrow[\mathrm{i}]$ & & & & $\sqrt{ }$ \\
\hline & $/ \mathrm{g}, \mathrm{k} / \rightarrow[\mathrm{gb}, \mathrm{kp}]$ & & & & $\sqrt{ }$ \\
\hline \multirow{2}{*}{$\begin{array}{l}\text { Reutralised } \\
\text { coalescence }\end{array}$} & $/ \mathrm{g} /+/ \mathrm{s} / \rightarrow[\mathrm{x}]$ & & & & $\sqrt{ }$ \\
\hline $\begin{array}{l}\text { Resists } \\
\text { assimilation }\end{array}$ & $/ \mathrm{mày}-1 \mathrm{l} / \rightarrow *[\mathrm{~g} / \rightarrow[\mathrm{g}]$ & & & & $\sqrt{ }$ \\
\hline
\end{tabular}

These conclusions may not be sufficient to entirely dismiss the position of complexity as a markedness diagnostic in all sub-disciplines of linguistics (e.g. morphology and syntax). However, such possibilities only re-ignite the question regarding the universality of some of the markedness diagnostics and the usefulness of markedness as a monolithic concept in accounting for the wide ranging phonetic and phonological distinctions for which it has been deployed over the decades. Whether many of the differences observed in linguistic units and patterns need to be accounted for using the concept of markedness is an issue that needs further scrutiny. 


\section{References}

Archangeli, D. (1984). Underspecification in Yawelmani phonology and morphology (Doctoral thesis). Massachusetts Institute of Technology. Retrieved from https://dspace.mit.edu/bitstream/handle/ 1721.1/15440/12859504-MIT.pdf?sequence=2.

Archangeli, D., \& Pulleyblank, D. (1989). Yoruba vowel harmony. Linguistic Inquiry, 20, 173-217.

Avery, P., \& Rice, K. (1989). Segment structure and coronal underspecification. Phonology, 6, 179-200.

Battistella, E. (1990). Markedness: The evaluative superstructure of language. Albany: SUNY Press.

Bauer, L. (1988). What is lenition? Journal of Linguistics, 24, 381-392.

Calabrese, A. (1995). A constraint-based theory of phonological markedness and simplification procedures. Linguistic Inquiry, 26, 373-463.

Cho, Y. (1988). Korean assimilation. In H. Borer (Ed.), Proceedings of WCCFL 7 (pp. 41-52). Stanford, CA: Stanford Linguistics Association.

Chomsky, N., \& Halle, M. (1968). The sound pattern of English. New York: Harper and Row.

Clements, G. (1985). The geometry of phonological features. Phonology Yearbook, 2, 225-252.

Clements, G., \& Hume, E. (1995). The internal organisation of speech sounds. In J. Goldsmith (Ed.) The handbook of phonological theory (pp. 245306). Cambridge, UK: Blackwell.

Dakubu, M.E.K., Atintono, S. \& Avea, N. (2007). Gurenc-English Dictionary. Vol. 1. Accra: University of Ghana, Legon.

de Lacy, P. (2002). The formal expression of markedness (Doctoral thesis). University of Massachusetts, Amherst. Retrieved from https://rucore.libraries.rutgers.edu/rutgers-lib/38430/PDF/1/.

de Lacy, P. (2006). Markedness: reduction and preservation in phonology. Cambridge, UK: Cambridge University Press.

Dresher, B. E., \& van der Hulst, H. (1993). Head-dependent asymmetries in phonology. Toronto working papers in linguistics, 12 (2), 1-17.

Givón, T. (1995). Markedness as meta-iconicity: distributional and cognitive correlates of syntactic structure. In T. Givón (Ed.), Functionalism and grammar (pp. 25-69). Amsterdam: John Benjamins.

Greenberg, J. (1966). Language universals, with special reference to feature hierarchies. The Hague: Mouton.

Greenberg J. (1969). Language universals: A research frontier. Science, 166, 473-478.

Hamilton, P. J. (1996). Phonetic constraints and markedness in the phonotactics of Australian aboriginal languages. (Doctoral thesis). University of Toronto. Toronto, Canada. Retrieved from https://twpl.library.utoronto.ca/index.php/twpl/article/ view/6520/3491. 
Harris, J. (1990). Segmental complexity and phonological government. Phonology, 7 (2), 255-300.

Haspelmath, M. (2006). Against markedness (and what to replace it with). Journal of Linguistics, 42 (1), 25-70.

Hockett, C. F. (1955). Manual of phonology. Baltimore: Waverly Press. Hudu, F. (2016). Vowel neutralisation and the vowel inventory of Dagbani: phonology, acoustics, perception. Journal of African Languages and Linguistics, 37(1), 59-89.

Hudu, F. (2014a). [ATR] feature involves a distinct tongue root articulation: Evidence from ultrasound imaging. Lingua, 143, 36-51.

Hudu, F. (2014b). What is a phonological word in Dagbani? A positional faithfulness account. Ghana Journal of Linguistics, 3 (1), 1-44.

Hudu, F. (2013). Dagbani tongue-root harmony: Triggers, targets and blockers. Journal of African Languages and Linguistics, 34 (1), 47-73.

Hudu, F. (2010). Dagbani tongue-root harmony. A formal account with ultrasound investigation. (Doctoral thesis). University of British Columbia, Vancouver, Canada. Retrieved from https://open.library.ubc.ca/cIRcle/collections/ubctheses/24/ items/1.0071197.

Hudu, F. (2005). Number marking in Dagbani (MA thesis). University of Alberta, Edmonton, Alberta, Canada. Retrieved from https://elibrary. $\mathrm{ru} / \mathrm{item}$.asp?id $=9382850$.

Hudu, F., Miller, A., \& Pulleyblank, D. (2009). Ultrasound imaging and theories of tongue root phenomena in African languages. In P. K. Austin, O. Bond, M. Charette, D. Nathan \& P. Sells (Eds.), Proceedings of Conference on Language Documentation and Linguistic Theory 2 (pp. 153-163). London: School of Oriental and African Studies.

Hume, E. (2011). Markedness. In M. van Oostendorp, C. J. Ewen, E. Hume \& K. Rice (Eds.), The Blackwell companion to phonology (pp. 79-106). Malden, MA: Blackwell Publishing.

Hume, E. (2003). Language specific markedness: The case of place of articulation. Studies in phonetics, phonology and morphology, 9, 295310.

Hume, E., \& Tserdanelis G. (2002). Labial unmarkedness in Sri Lankan Portuguese Creole. Phonology, 19 (3), 441-458.

Iverson, G., \& Kim, K. H. (1987). Underspecification and hierarchical feature representation in Korean consonantal phonology." In A. Bosch, B. Need\& E. Schiller (Eds.), Proceedings of Chicago Linguistics Society 23 (pp.182-198). Chicago: Chicago Linguistic Society.

Kiparsky, P. (1982). Lexical morphology and phonology. In I. S. Yang (Ed.), Linguistics in the morning calm (pp. 3-91). Seoul: Hanshin Publishing.

Kirchner, R. (1998). An effort-based approach to consonant lenition. (Doctoral thesis). University of California, Los Angeles. Retrieved from https://rucore.libraries.rutgers.edu/rutgers-lib/38310/PDF/1/. 
Ladefoged, P. (1968). A phonetic study of West African languages: An auditoryinstrumental survey. ( $2^{\text {nd }}$ ed.). Cambridge, UK: Cambridge University Press.

McCarthy, J. \& Prince, A. (1994). The emergence of the unmarked: Optimality in prosodic morphology. In M. Gonzàlez (Ed.), Proceedings of the North-East Linguistic Society 24 (pp. 333-79). Amherst, MA: Graduate Linguistic Students Association.

Miehe, G. (2012). Dagbani. In G. Miehe, B. Reineke \& K. Winkelmann (Eds), Noun class systems in Gur languages Vol. 2 (pp. 330-349). Cologne, Germany: Rüdiger Köppe Verlag.

Miehe, G, M., Reineke, B., \& Winkelmann, K. (Eds.). (2012). Noun class systems in Gur languages Vol. 2. Cologne, Germany: Rüdiger Köppe Verlag.

Naden, T. (2014). Dagbani dictionary. Tamale: Ghana Institute of Linguistics, Literacy and Bible Translation.

Newmeyer, F. (1992). Iconicity and generative grammar. Language 68 (4), 756796.

Odden, D. (1991). Vowel geometry. Phonology, 8 (2), 261-289.

Ohala, J., \& Lorentz, J. (1977). The story of [w]: An exercise in the phonetic explanation for sound patterns. In K. Whistler, R. jr. van Valin, C. Chiarelloet al (Eds.), Proceedings of the the Berkeley Linguistic Society (pp. 577-599). Berkeley, CA: Berkeley Linguistics Society.

Olawsky, K. (1999). Aspects of Dagbani grammar - with special emphasis on phonology and morphology. Muenchen: Lincom Europa.

Padgett, J. (1995). Partial class behaviour and nasal place assimilation. Proceedings of the Arizona Phonology Conference: Workshop on Features in Optimality Theory (pp. 145-183). University of Arizona, Tucson: Coyote Working Papers.

Paradis, C., \& J. Prunet. (1991). Asymmetry and visibility in consonant articulations. In C. Paradis \& J. Prunet (Eds.), The special status of coronals: Internal and external evidence (pp. 1-28). San Diego, CA: Academic Press.

Pulleyblank, D. (1988). Vocalic underspecification in Yoruba. Linguistic Inquiry, 19 (2), 233-270.

Rice, K. (2007). Markedness in phonology. In P. de Lacy (Ed.), The Cambridge handbook of Phonology (pp. 79-97). Cambridge, UK: Cambridge University Press.

Rice, K. (1996). Default variability: The coronal-velar relationship. Natural Language \& Linguistic Theory, 14 (3), 493-543.

Rice, K. (1994). Peripheral in consonants, Canadian Journal of Linguistics, 39 (3), 191-216.

Rice, K. (1992). On deriving sonority: A structural account of sonority relationships. Phonology, 9 (1), 61-99. 
Hudu, F./ Asymmetries in the phonological behaviour of Dagbani place features

Sagey, E. (1986). The representation of features and relations in non-linear phonology (Doctoral Thesis). Massachusetts Institute of Technology. Retrieved from https://dspace.mit.edu/bitstream/ handle/1721.1/15106/15862473-MIT.pdf?sequence=2 .

Stemberger, J. (1992). Vocalic underspecification in English language production. Language, 68 (3), 492- 524.

Trubetzkoy, N. (1939/1969). Principles of phonology. Berkeley, CA: University of California Press. Waugh, L. R., \& B. A. Lafford. (1994). Markedness. In R. E. Asher (Ed.), Encyclopaedia of languages and linguistics (pp. 2378-2383). Oxford, UK: Pergamon Press.

Wilson, W.A.A. \& Bendor-Samuel, J. T. (1969). The phonology of the nominal in Dagbani. Linguistics, 7 (52), 56-82. 